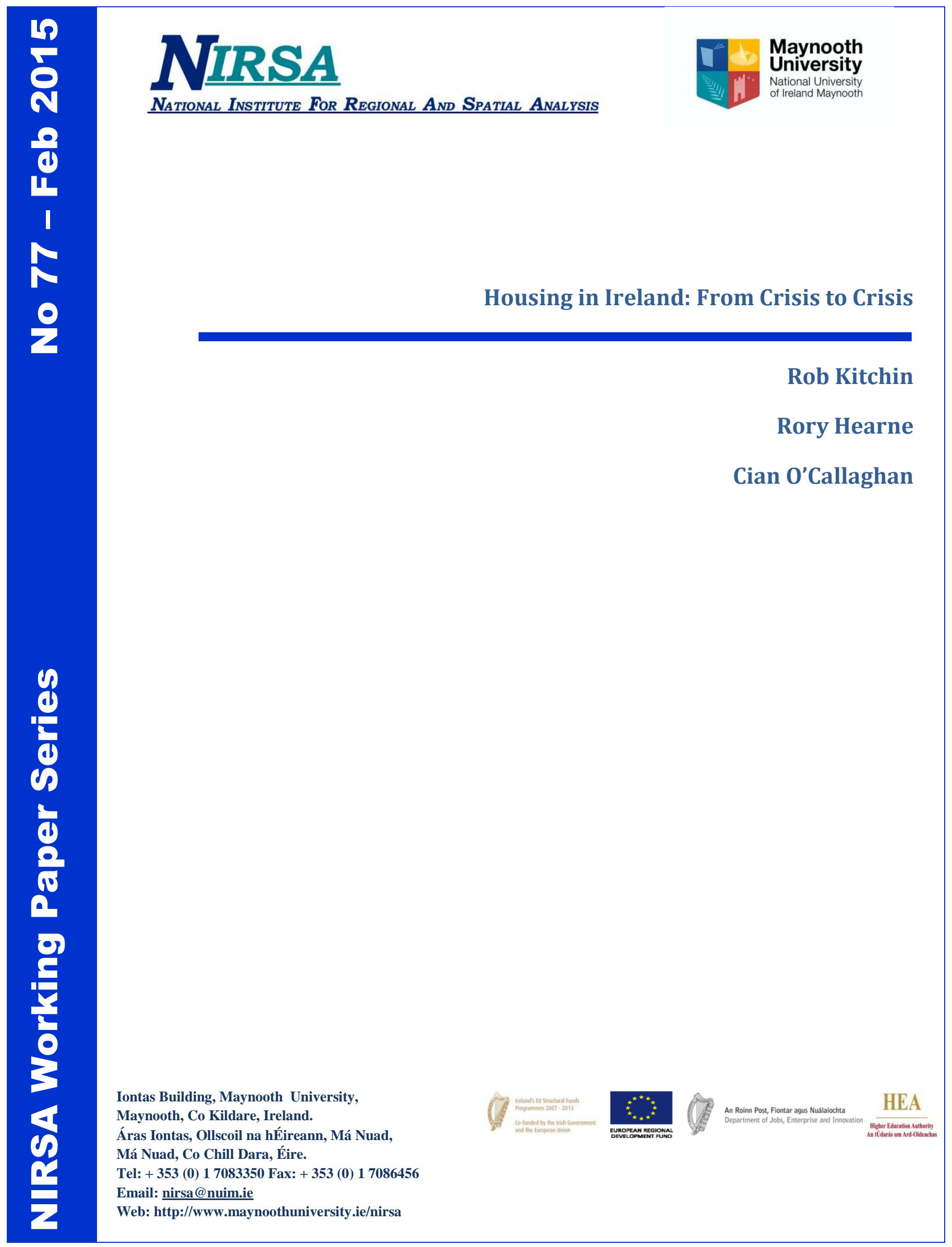




\section{Housing in Ireland: from crisis to crisis}

Rob Kitchin, Rory Hearne and Cian O'Callaghan

Department of Geography \& National Institute for Regional and Spatial Analysis, National University of Ireland Maynooth, County Kildare, Ireland.

Rob.Kitchin@nuim.ie, Rory.Hearne@ nuim.ie and Cian.OCallaghan@nuim.ie

For Austerity: The Irish Experience, edited by Andrea Prothero and William K. Roche

\section{Introduction}

Housing can be an incredibly emotive issue. Shelter and a sense of home is essential to our well-being, which is why the right to housing is enshrined in the conventions of the United Nations and, in turn, ratified by most national governments. Housing provides us with sanctuary, a sense of identity and belonging, a firm base from which to venture out into the wider world. Housing is also seen as an asset: the most expensive purchase most families make or an investment for landlords seeking a steady yield. Building and selling houses can be highly profitable, but they can also bankrupt households, builders, developers and banks if the market plummets. Losing one's home is highly distressing, as is the sense that one cannot afford a home due to changing house or rental prices. Living in substandard housing or being homeless can be detrimental to one's mental and physical health. Providing high quality, affordable and securely tenured housing for all citizens is thus a core stated ambition of most governments. However, there is a marked difference between rhetoric and reality, in part due to the ideology of ruling parties and the machinations of vested interests, but also due to housing being a complex and costly endeavour. Furthermore, there is also increasingly a tension between housing as a form of shelter (its use value) and housing as an asset class (its exchange value), particularly in light of the finanzialization of mortgage markets (Aalbers, 2008)

The central thesis we advance in this essay is that housing in Ireland is perpetually in crisis -- that the issues noted above and others are prevalent, effecting many households, especially those with a mortgage, those renting, and those residing in or waiting for social housing. What is more the crisis in housing pre-dates the crash of 2007/8, building up for at 
least twenty years and evolving through three distinct phases: 1993-2006 (the Celtic Tiger years); 2007-2012 (the crash); 2013- (unstable, uneven and partial rebalancing). The crises of phases two and three were created by the outcomes and policies adopted during phase one, and have been deepened by recent austerity policies, placing severe stresses on households and the housing sector. The chapter traces out trends, policy and the multiple crises operating within each of these periods and how they have negatively impacted on housing in Ireland, especially in the post-crash era. The conclusion sets out why housing in Ireland evolved through these crises and examines what might be done to solve them and provide more robust housing policies that will ameliorate against future boom and bust cycles and help transition the country out of austerity.

\section{Crisis phase 1: 1993-2006 (the Celtic Tiger years)}

The exact start date of the Celtic Tiger era is still debated, but most commentators accept it was between 1991 and 1995. What is clear is that from the early 1990s the Irish economy began to transform with a notable rise in key economic indicators such as GDP and numbers in employment. As the economy grew, the population increased through immigration and natural increase and average household size shrank through alterations in family structure. Between April 1991 and April 2006 the population of Ireland increased by 704,129 (20\%), the number of households by 440,437 (43\%) (CSO 2014a). The demand for housing thus expanded rapidly, as did the need to produce a more diversified stock that would cater for different sized and types of household. While population and households fell in some localised areas, it increased overall in each local authority, and in some it expanded very rapidly. For example, in Kildare and Meath the number of households grew by $85 \%$ and 87\%. This demand had six effects, all of which can be considered a crisis in its own right given its dramatic transformative effect and demands: the development of a large construction boom as developers sought to produce a large quantity of housing supply; a surge in house prices as households competed for seemingly limited stock, especially in prime locations; a large increase in household debt, especially relating to mortgage debt; an increase in land zoning for new development and speculative acquisitions of land leading to a dramatic increase in prices; a significant increase in bank indebtedness as they borrowed on the international markets to lend to developers; and the rapid expansion of urban sprawl and long distance commuting. To take each of these in turn. 
Between January 1991 and December 2006 762,631 housing units were completed in Ireland, peaking with 93,419 units being built in 2006 alone (see Figure 1; DECLG 2014). Even allowing for replacing obsolescent stock, clearly more units were being built than there were households being formed, especially in the period 2002-06, sowing the seeds for the second phase of crises. Nonetheless, house prices grew dramatically. The average new house price rose from $€ 78,715$ in Dublin and $€ 66,914$ for the country as a whole in 1991, to $€ 416,225$ in Dublin (a 429\% increase) and €322,634 for the country as a whole (a $382 \%$ increase) in 2007 (DECLG 2014). Secondhand homes followed the same trend, with homes in Dublin rising by $551 \%$ and $489 \%$ outside the capital. In the same period house building costs and wages only doubled (Brawn, 2009). In Q3 of 1995, the average secondhand house price was 4.1 times the average industrial wage of $€ 18,152$; by Q2 of 2007 secondhand house prices had risen to 11.9 times the average industrial wage of $€ 32,616$ (Brawn, 2009). Not unsurprisingly, the total value of household mortgage debt increased dramatically, from $€ 47.2$ billion in 2002 to over $€ 139.8$ billion at the end of 2007 , with the average size of a new mortgage (€266,000) being nearly double the 2002 figure (CSO, 2008). During this period a 'bubble economy', underpinned by the expansion of debt to households based on perceived increases in the value of their homes, drove economic growth (O'Riain, 2014). Moreover, given rapidly rising prices and a strong rental market, the buy-to-let market flourished, with a significant number of households becoming 'amateur' landlords. At the same time, state investment into social housing was waning whilst demand was growing, with a turn to the private sector to provide accommodation through a rent supplement scheme. Further, social housing built during the 1950s was coming to the end of its life, needing either substantial refurbishment or replacement.

Figure 1: Number of completed housing units per annum, 1991-2013

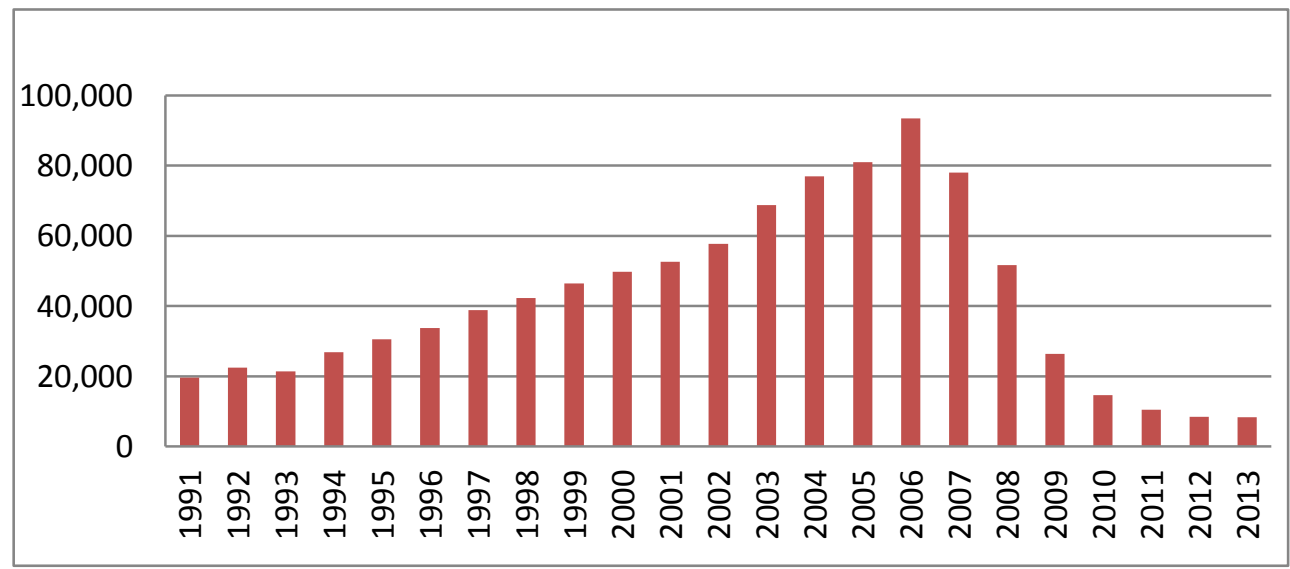


Given the demand for prime land for development, pressure was placed on local authorities to zone more land and the cost of land rose dramatically, especially in 2004-06 (see Figure 2). Land prices jumped in value from just under $€ 10,000$ per hectare in 1998 to over $€ 58,400$ per hectare in 2006 (Savills HOK, 2007). This made Irish land the most expensive in Europe: nearly twice the price per hectare of any other European country, and three times greater than that in all but four countries. The result was that land became a significant component of housing cost: up to $50 \%$ as against a European average of $10-15 \%$ (O'Toole, 2009). To enable developers to bid for land and to afford the cost of building bank lending increased substantially. In 2003 the indebtedness of Irish banks to overseas banks was just over $10 \%$ of Irish GDP. By 2008 this had risen to $60 \%$ of GDP, with over $60 \%$ of bank assets tied up in property-related lending (Honohan 2010).

Figure 2: (a) land prices in Ireland 1973-2006 (b) land prices in Europe in 2006
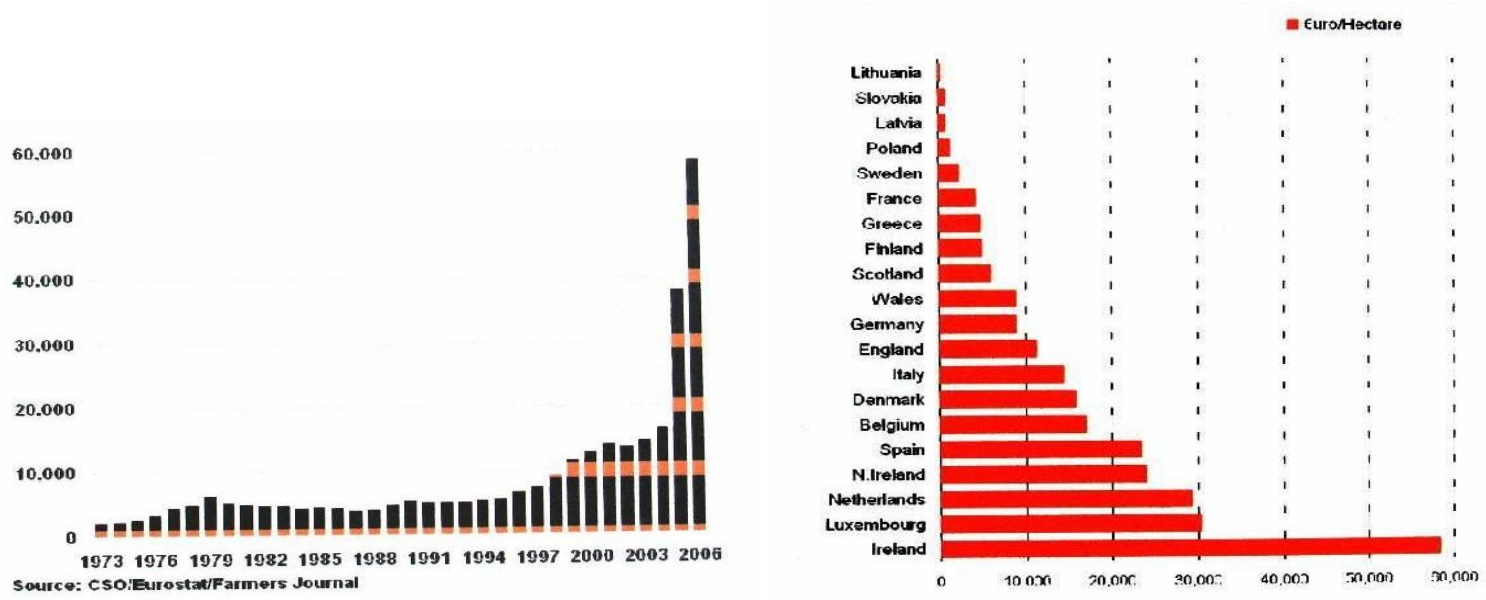

Source: HOK Savills (2007)

Given the cost of land and housing, households who wished to buy a home but who had limited resources were forced to either buy property that did not suit their future needs with the aim of trading up later (e.g., a one or two bed apartment, with the aim of a family home in due course), borrowing beyond their means (e.g., 100\% or interest-only mortgages; or taking out multiple loans), or buying in an area further away and commuting. These factors created a context in which a growing number of households had a vested interest in property prices rising further, thus extending a debt-based model of home-ownership and 
perpetuating these trends. Furthermore, the reliance on long distance commuting led to extensive urban sprawl and the growth of smaller towns around the principal cities and towns (hence the already noted increase in households in Kildare and Meath), mainly reliant on car travel given the limited public transport network. In many cases, the long distance commute was well in excess of an hour and half each way and placed a significant fuel cost burden on the household, especially as petrol/diesel costs grew in the 2000s.

Somewhat ironically, all of these changes were celebrated by the government, the construction sector, and the media during the Celtic Tiger era. They were taken as a sign that Ireland was catching up with the rest of the developed West in terms of its economy and property sector. It was suggested that a virtuous circle had been created whereby people stepping onto the property ladder were immediately gaining the benefit in their prime asset rising in price, and moreover they had more choice in housing options than ever before; the government was collecting significant tax revenue (VAT, capital gains tax, stamp duty, development levies) that could be re-invested into improved services and infrastructure; and the property and banking sector were flourishing whilst helping to bring in overseas investment. Whilst price rises were staggering, potential purchasers and investors were assured that there was still plenty of scope for further expansion. And anyone who suggested that these changes were potentially very harmful to households by saddling them with huge debt and unsustainable commutes, and to the wider Irish economy by reducing competitiveness and producing a bubble that was sure to burst, were roundly attacked by politicians, the media, and the property sector. The worst that could happen they were told was a soft landing, wherein prices levelled off to modest growth, and construction slowed in pace. But the bubble did burst, with devastating consequences for citizens, companies and the state.

\section{Crisis phase 2: 2007-2012 (the crash)}

As the global economy slowed and the global sub-prime banking crisis began house price rises in Ireland started to slow in September 2006, levelling off in March 2007 and remaining static until November 2007. From December 2007 to February 2012 they fell consistently, before bottoming out and remaining stable until June 2013 (see Figure 3). From the peak to bottom prices fell by $57.4 \%$ in Dublin (houses $55.9 \%$ and apartments $63.7 \%$ ) and $48.7 \%$ in the rest of the country (CSO 2014b). Ireland experienced one of the deepest house market collapses on record. What was happening with house prices was a barometer for the wider 
housing sector. As 2008 started it was clear that the promise of a soft landing was empty and all of the issues built up over the course of the Celtic Tiger years -- massive growth in housing and land prices, household and bank debt, over-zoning and over-building -- exploded into a new set of crises as the property bubble burst and the Irish banking sector collapsed (between May 2007 and November 2008 Irish bank shares fell in value from $€ 55$ billion to $€ 4$ billion; Murphy and Devlin, 2009), culminating in the Irish bank guarantee of September 2008, the creation of the state-owned National Assets Management Agency (NAMA) in September 2009 (which bought $€ 74$ billion of distressed property loans from the Irish banks), and the $€ 85$ billion IMF-EU-ECB bailout in November 2010 (see Kitchin et al., 2012).

Figure 3: Overall \% change of residential price from 2007 peak

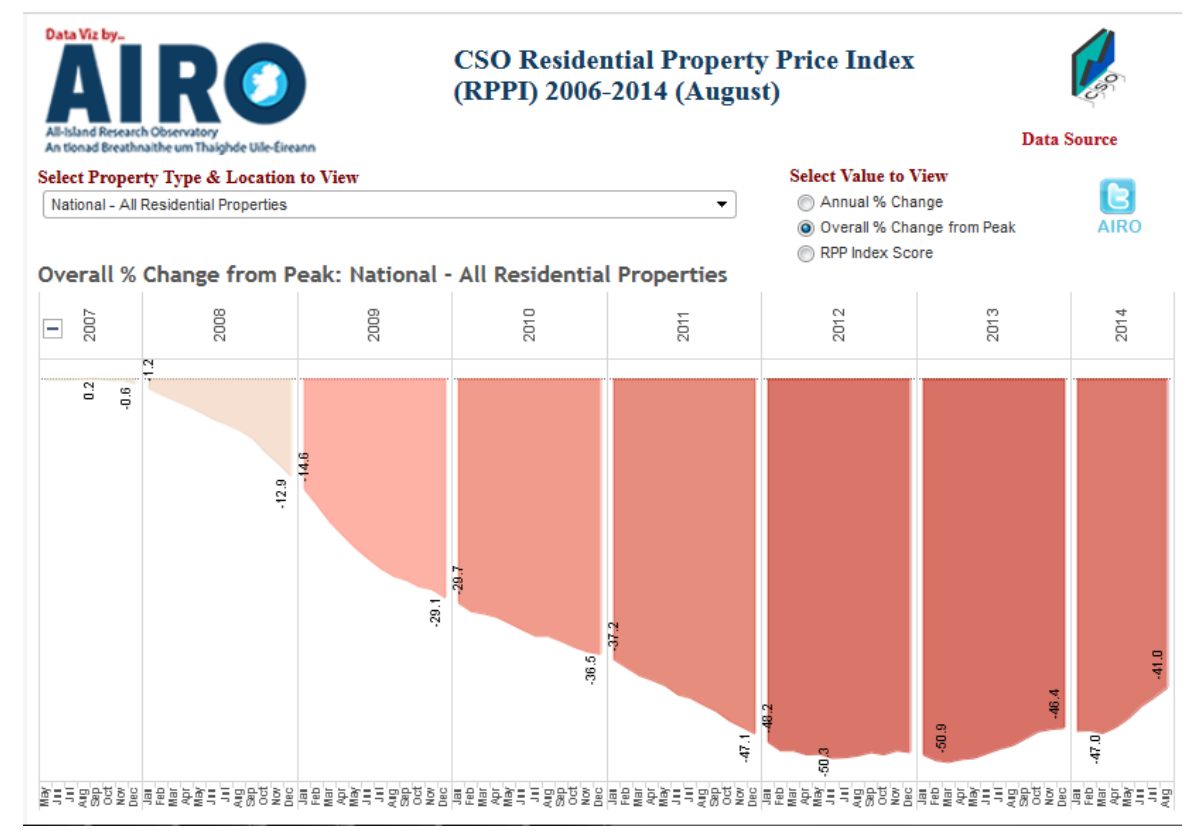

Source of data: CSO (2014b)

Whilst the global financial crisis was the trigger to the Irish crisis, Irish banks were little exposed to subprime loans; rather, as noted, they were massively exposed to property loans in a bubble market, with a highly active construction sector and rabid land speculation (O'Toole, 2009). Significantly exacerbating the situation was it soon became clear that not only were prices over-inflated, but that there was a massive oversupply of housing stock and over-zoning of land. Between 2005 and 2007 252,403housing units were completed in Ireland (connected to the electricity grid), with another 78,144 added in 2008 and 2009 as legacy construction slowed (DECLG 2014). This is despite the fact that the 2002 census had 
reported 177,254 vacant units (excluding holiday homes) and the 2006 census 216,533 vacant units (excluding holiday homes) (CSO 2014a). Put simply, housing units had been built in excess of demand across the entire country, with several local authorities having vacancy rates excluding holiday homes above $15 \%$. The extent of the oversupply was clarified by the 2011 census, which reported that 230,056 units were vacant (excluding holiday homes), 168,427 houses and 61,629 apartments out of a total housing stock of 1,994,845 (CSO 2012). Allowing that one would always expect some units to be vacant in any housing market (the Department of Environment, Community and Local Government (DECLG) suggest 6\%) then oversupply was approximately 110,000 units. With supply outstripping demand, there was no demand to support existing prices, moreover even if there was, there was no credit to enable purchases due to the banking crisis.

The most visible manifestation of the oversupply issue were and continue to be unfinished estates. After some speculation as to how many such estates existed in Irish towns, cities and countryside, the DECLG undertook a nationwide survey in 2010. The National Survey of Housing Developments reported that there were 2,846 documented unfinished estates in Ireland, present in every local authority, of which only 429 were still active (Housing Agency 2010; see Figure 4). With respect to the units on these estates, 78,195 were complete and occupied, 23,250 complete and vacant, and 19,830 under construction, with planning permission in place for a further 58,025 units. The 2013 survey recorded 1,811 estates, which all had outstanding issues of planning and development (with estates with issues of vacancy only excluded), on which there were 82,432 dwellings: 57,642 complete and occupied, 8,694 complete and vacant, and 16,135 under-construction (19.6\%) (Housing Agency 2013). Only 193 recorded development activity. Of these 82,432 dwellings, $47.9 \%$ had incomplete roads, $18.7 \%$ incomplete footpaths, $21.9 \%$ incomplete lighting, 19.4\% lacked potable water, $18.6 \%$ lacked fully operational storm water systems and $19.4 \%$ lacked fully operational waste water systems. Of 4,033 planned open space areas, only 2,205 were complete. 
Figure 4: Unfinished estates in Ireland in 2010

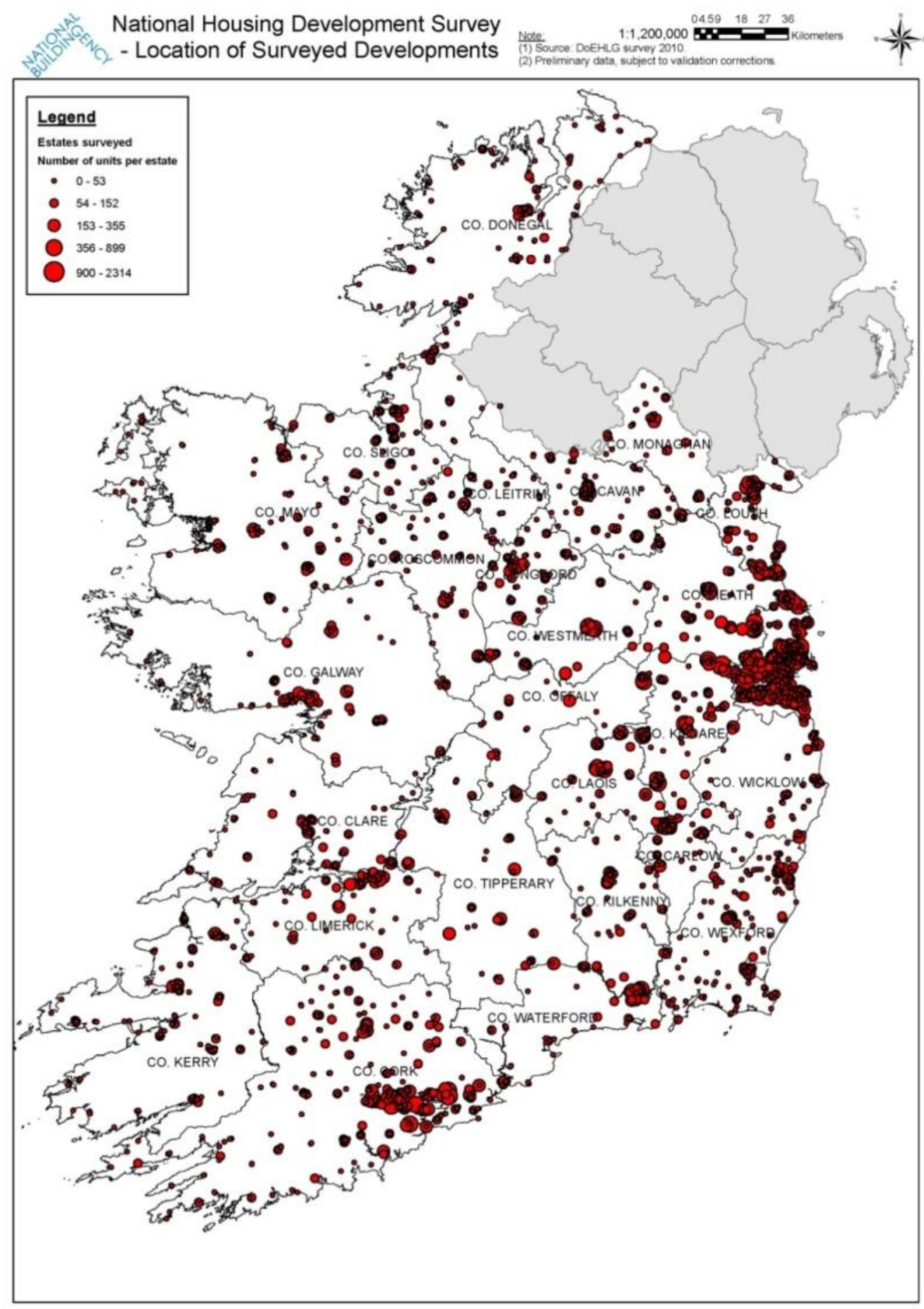

Beyond the levels of incompleteness and the lack of key services such as roads, paths, public lighting, drinkable water, and sewage systems, those households who found themselves residing on these unfinished estates have also had to contend with anti-social behaviour and vandalism, with empty units being used for parties, brothels, the selling of drugs, squatting, and so on, an unsafe environment for children to play in, isolation from 
neighbours and a diminished sense of place, and in some rural areas poor access to services such as schools, crèches, medical centres and public transport (Kitchin et al., 2014). In cases where an estate management company was meant to be in place, low levels of occupancy made such companies unviable, meaning that service provision has been patchy or nonexistent (Mahon and O'Cinneide 2010). There has also been the stress of an uncertain future with regards to the situation improving and personal finances concerning mortgage payments and negative equity. Severe cutbacks in government spending and austerity budgets meant that a minimum policy, minimum cost approach has been taken with respect to unfinished estates, with the government initially allocating just $€ 5 \mathrm{~m}$ for tackling health and safety issues (e.g., knocking down unsafe structures, fencing off and tidying up areas) and seeking to establish Site Resolution Plans (SRPs) for each estate. SRPs are plans collectively put together by all vested interests -- local authorities, developers, banks, residents -- and provide a roadmap for how to deal with issues on an estate, but crucially are voluntary and have no statutory tools beyond existing legislation that are difficult to apply to bankrupted entities, nor finances beyond the government fund. As such, the extent to which outstanding problems are addressed through SRPs varies widely between different local authorities and different estates. What that has meant is that seven years after the start of the crisis, many unfinished estates remain unfinished and residents continue to live with a range of on-going issues.

Beyond vacancy and unfinished estates, there has been a concern related to the quality of dwellings constructed during the Celtic Tiger era. Building control and standards were deregulated in Ireland in 1990, with local authority planning enforcement only undertaking inspections on $10-15 \%$ of sites and not at all stages of development. Self-certification, plus high volume construction, meant that many sub-standard units were built, along with units that met minimum standards. Many units or extensions were built without planning permission or building control certification, making them now difficult to sell as banks tighten up the conditions for lending. The highest profile case relates to Priory Hall, where 187 apartments were found to breach fire hazard regulations, with residents forced to vacate their homes for two years whilst continuing to pay mortgages, but there have been numerous other similar examples. Further, there are estimated to be in excess of 20,000 homes whose foundation hardcore and building blocks are contaminated with pyrite, though the DECLG presently only recognizes 74 estates containing 12,250 units, predominately located in Dublin City, Fingal, Meath, Kildare, and Offaly (DECLG 2012). Again, the government response 
has been a minimum approach that seeks to minimize any costs to the state, and in some cases actively working against resident interests, such as with Priory Hall.

In addition to oversupply of dwellings, there was also an oversupply of zoned land and commercial premises. In June 2008, there was 14,191 hectares of serviced zoned land in the state, enough for up to 462,000 potential new units (DECLG 2014). In addition, there was another 30,000 hectares of unserviced zoned land. In many parts of the country there was enough zoned land for dozens of years of supply, with the average being 16.8 years if the household growth with each local authority continued at the same pace as 1996-2006 (a period of rapid growth) (Kitchin et al., 2010). For example, in Monaghan, a mostly rural local authority with a housing stock of 21,658 units in 2006 there was enough zoned land for an additional 18,147 units, enough to last for over 50 years. Not unsurprisingly land prices plummeted by between $75-98 \%$ in value post-2007. In Dublin some $782,500 \mathrm{~m}^{2}$ of office space (23\%) was vacant in 2010 (Savills HOK 2010). After a substantial growth in the construction of hotels during the Celtic Tiger, at the end of 2008 15,000 guest rooms (26\%) were deemed to be in-excess of demand (Bacon and Associates, 2009). And while there are no figures on the extend of vacant retail space, shopping centre and retail park space doubled between 2005 and 2010 to 2 million $\mathrm{m}^{2}$ and 1.32 million $\mathrm{m}^{2}$ respectively (CBRE, 2010). Much of these commercial properties ended up in NAMA.

As the housing market plummeted and the wider economy crashed, with unemployment rising from 4.6\% in Q4 2007 to peak at 15.1\% in Q3 2011 and households facing tax rises and pay cuts, increasing financial pressure was placed onto households (CSO 2014c). Faced with paying high payment rates on their mortgages many households struggled to keep up with payments. In Q3 $20093.3 \%$ of principal residence mortgages were in arrears by more than 90 days. By Q3 2013 this had peaked at 12.9\% (99,189 mortgages) in arrears over 90 days, with 18.4\% in some level of arrears (141,520) (Central Bank 2013). With respect to buy-to-let mortgages, $21.2 \%(31,227)$ were in arrears of more than 90 days, with 27.4\% (40,426) in some level of arrears in Q3 2013. And as house prices dropped, the number of households in negative equity grew to include more than $50 \%$ of residential properties with a mortgage (RTÉ 2012). While any loss on a property is not realised unless the dwelling is sold, negative equity acts as a spatial trap, constraining the owner from selling to escape mortgage arrears, or to trade up or down for more suitable accommodation given changes in family circumstance, or is unable to move areas to seek work. Similarly, rent 
arrears to local authorities, borough and town councils increased from $€ 32.8 \mathrm{~m}$ in January 2008 to $€ 58.5 \mathrm{~m}$ in December 2011 as tenants struggled to pay their bills (DECLG 2014).

The huge house price rises in the Celtic Tiger years, followed by the financial pressures of the crash, had significant spillover effects with respect to social housing demands and homelessness. In 1999 there were 39,176 households on the social housing waiting list, rising to 48,413 in 2002, 56,249 in 2008, and 98,318 in 2011 (DECLG 2014). The vast majority of people on the list are because they cannot afford to purchase or privately rented accommodation. Between 1994 and 2007 47,769 social housing units were built in Ireland, plus between 1999 and 2007 9,378 were acquired through purchase and 1,201 longterm leases acquired through the Rental Accommodation Scheme (RAS) (DECLG 2014). At the same time 22,633 local authority units were sold to tenants (many of these funded by mortgages provided by local authorities, a large proportion of which are now in arrears). However, the austerity programme implemented by two governments from 2008 onwards dramatically reduced state investment in social housing. The capital expenditure for social housing was reduced by $80 \%$ (from $€ 1.3 \mathrm{bn}$ to $€ 275 \mathrm{~m}$ ) between 2008 and 2013 and funding for the National Regeneration Programme reduced from $€ 121$ million in 2008 to $€ 80$ million in 2013 a 34\% reduction. Social housing was disproportionately cut under austerity in comparison to other sectoral budget reductions. As a result between 2008 and 2013, 10,745 social housing units were built (nearly all -- 8,267 -- in 2008-09, much of it replacement stock in regeneration schemes), 3,293 were acquired through purchase and 8,707 long-term leases were acquired through RAS. While some stock was being built or acquired then, social housing needs were outstripping the state's ability to supply suitable affordable accommodation. Indeed, the proportion of social housing stock has fallen from $18 \%$ of all residences in 1961 to $8 \%$ in 2011 (CSO 2012). The shortfall in social housing is made-up through privately rented accommodation subsidized by rent supplement. 97,260 households were receiving rent supplement in late 2010, an increase of $63 \%$ on the previous three years, with spending rising from $€ 70$ million in the mid-1990s to $€ 516.5$ million in 2010 . Even with the state providing social housing or rent supplement, the financial and other pressures placed onto individuals and households during the crash saw a rise in homelessness: between 2008 and 2011 the number of homeless households increased by $68 \%$ to 2,348 , with 3,808 people in accommodation for the homeless, of which 1,648 (including 457 children under the age of 15) were in emergency accommodation (Housing Agency 2011: 12). 
Further, much social housing stock is acknowledged to be in poor condition and also suffers strong social and economic disadvantage with social problems, high unemployment, drug addiction, gang-related crime, and low education participation rates. After extensive local community campaigning, prior to the crash the decision was to taken for large-scale regeneration schemes in North Dublin (Ballymun) and other Dublin estates, Limerick (Moyross and St Mary's), and a number of regional towns, including Sligo, Dundalk and Tralee. The funding mechanism for such regeneration was public-private partnerships (PPPs), involving a transfer of local authority land to a private developer who would then build and sell owner-occupier housing and commercial/retail units in return for providing a reduced amount of new social housing and some community facilities on the remainder of the site (Hearne 2011). The use of PPPs for regeneration would, it was argued, create a better social-mix, diminishing concentrations of social- and low-income-housing (DEHLG, 2005). These schemes collapsed with the crash as both private and public finances evaporated. This left thousands of local authority tenants living in substandard conditions whilst awaiting relocation and many hundreds permanently relocated in preparation for regeneration. Given that old units were slated for demolition and were now half or more empty, and the reduction in local authority maintenance budgets, conditions in these estates deteriorated further, condemning families to live in unhealthy and unsafe environments. At the same, planned investment in Traveller accommodation also stalled during this period, with 361 Traveller families in living on unauthorised sites, 2717 in private rented accommodation, and 663 in shared housing in 2013 (DECLG 2014).

\section{Crisis phase 3: 2013- (unstable, uneven and partial rebalancing)}

The levelling off in the fall in house prices, followed by a gradual and then rapid increase of prices in Dublin (rising by $24.1 \%$ between October 2012 and 2013), is indicative of the start of a new phase in the ongoing housing crisis. This phase sees the continuation of serious problems of phase 2, such as social housing need, private rent rises, mortgage arrears, negative equity, unfinished estates, but varying levels of change depending on the extent to which solutions are put in place and the wider economy starts to recover. For example, 117,889 (15.5 per cent) of mortgage accounts remain in arrears. The numbers of PDH (private dwelling home) mortgages in arrears for 90 days, while dropping $14.3 \%$ year-on-year , remains at 84,955 to the value of $€ 16.6$ billion (Central Bank 2014). There has been little change in the buy-to-let (BTL) mortgage accounts with 15,435 BTL in arrears over 720 days. 
Half of what is being classed as 'restructuring' for those in arrears involve the issuing of legal repossession notices. Thus 50,000 PDH households have been issued with legal letters seeking repossession and full court proceedings to repossess homes have been initiated in 23,751 cases. On the buy-to-let side 18,000 mortgage accounts have been issued with repossession letters and 8,618 with court proceedings. The numbers receiving rent supplement fell by 23\% from 2010 to 74,080 (Irish Times 2014a). Large-scale dezoning significantly reduced the amount of serviced zoned land.

The new or deepening crises in this period are a lack of supply in some areas and associated rapidly rising housing and rental prices, continued problems of social housing provision, and rising homelessness in response to a changing rental market. On a structural level, these problems are to an extent the outcome of policies that have not systematically addressed the imbalances created by the bubble economy, but rather have acted to delay the onset of future crises of mortgage debt while relying on market mechanisms (Downey, 2014).

Whilst there was oversupply in every single local authority for both houses and apartments (with the exception of South Dublin for houses) in 2011 (Kitchin et al., 2010), the extent of this oversupply varied geographically. Much of rural Ireland had extensive levels of vacancy. In Dublin, the overall vacancy rate for the four local authorities was $8.3 \%$ (43,707 units; 25,333 of which were apartments) (CSO 2012). While the vacancy rate of houses was low, with only small pockets of oversupply, the vacancy rate for apartments was 16-19\%. Since 2011, despite emigration nationally, population and households have been growing in Dublin through natural increase, labour migration, and household fragmentation. Moreover, the levelling off of prices instilled confidence that the bottom of the market had been reached. In combination, the result was an increase in demand by investors trying to maximize return on investment and rental yields and households looking to enter the market. What oversupply there was in the capital has thus been absorbed, especially in desirable areas. With respect to new supply, however, construction has remained moribund. In 2012 only 8,488 units were built nationwide, 1,266 of which were in Dublin, and in 2013 only 8,301 units were completed nationwide, 1,360 of which were in Dublin (see Figure 1; DECLG 2014). In Q1 2014, only 509 units had been completed in the four Dublin local authorities. The effect of very little new supply for either purchase or rent, but rising demand, has led to the inflation in prices. Daft.ie reported in November 2014 that rents in Dublin are $15 \%$ higher than a year previously. 
One the effects of rent increases is that families who are income insecure - low wage, uncertain hours, flexible working, dependent on welfare - who reside in private rental accommodation cannot afford rent increases and rent supplement is not sufficient to cover the gap as more than half of those receiving rent supplement $(40,000)$ have to top up their rent. Consequently, they are being priced out of their homes in favour of those who can afford the new rental price. Such pressure is not aided by tenants often not knowing their full rights or seeking redress through the Private Residential Tenancies Board. These families find it difficult to find alternative private rented accommodation due to rent inflation across the rental sector and landlord preferences for tenants not reliant on rent supplement and discrimination against such tenants. With no social housing available, these families find themselves homeless. Nationally, the Simon Community report that in 2012, there was an increase of 24 per cent in those using their services, to over 5,000 individuals and families (Irish Times 2014b). The Dublin Region Homeless Executive detail that in 2013 a total of 4,613 unique individual adults used homeless services in Dublin (across all funded NGO's and statutory services). They report that demand has strengthened and changed in character since Autumn 2013 with more families with child dependents experiencing homelessness. During the week beginning April $28^{\text {th }} 2014$, the DRHE confirmed there were 184 households with dependent children accommodated in 21 commercial hotels across the Dublin region in lieu of provision of more suitable emergency accommodation for families due to a lack of capacity in usual emergency accommodation. The majority of these families were welfare dependent private tenants. The decision to use hotels is seen as a last resort taken in order to prevent any increase in rough sleeping in Dublin, especially among adults with dependent children. Dublin's homeless services secured an exit to tenancies and independent living for 793 persons in 2013. This is down by 10 per cent on the previous year's 879 exits, and a similar downward trend exists for 2014 due to a lack of suitable accommodation.

Assessments by both the Housing Agency and the Economic Social Research Institute (ESRI) suggest that without a significant increase in the level of supply that competition for property is going to get worse, with rising purchase and rental prices and increasing homelessness. The ESRI report (Morgenroth, 2014) detailed projected housing supply need until 2021. It argued that there will be an increase in household demand of 180,000 units, but because of oversupply in many parts of the country only 90,000 new units will need to be built, some 12,500 per year. 56,000 (60\%) of these need to be in Dublin, 8,000 per year. 26\% more will need to be in the Dublin commuter counties of Meath, Kildare, Louth and 
Wicklow. Overall, $86 \%$ of all new build will need to be in the Greater Dublin region. However, in many counties, the report suggests that new supply will not be needed because of existing oversupply. Indeed, Donegal, Kerry, Mayo, Tipperary, and all the Upper Shannon counties of Leitrim, Sligo, Cavan, Roscommon and Longford are projected to still have oversupply in 2021. The Housing Agency (2014) report analyzed housing need for 272 towns and cities across the country for the period 2014-18. It argued that there was a need for 80,000 new units, or 16,000 per annum. 37,500 units (47\%) would need to be built in Dublin, or 7,500 units per annum. The overall national required rate of between $12,500-16,000$ per annum is actually quite modest. Typically over the past forty five years new build has been 20-30,000 per annum, rising to 40,000+ post 1998. Indeed, 12,500 is in fact lower that the lowest build rate going back to when DECLG records start in 1970.

In theory, a lot of the right criteria for creating supply exist. There is an excess of demand: there are 6,400 acres of zoned serviced land available in the four Dublin authorities for 132,000 units (DECLG 2014); there are a lot of outstanding planning permissions still in effect and local authorities want to give permission for developments that meet development plan/zoning criteria; and material and labour costs of significantly lower than the boom time. Yet despite these conditions and the need to create supply it is clear that a hangover from phase 2 of the crisis is blocking development. The state's finances are limited, there are competing demands for scarce resources, and they are reluctant to significantly increase capital spending on housing and associated infrastructure. The banks are in a weak state and reluctant to lend for development. Builders and developers have no initial capital to draw down additional finance. With respect to land, it may be the case that owners are reluctant to put into development because they bought it in the boom and cannot afford to develop at present housing prices. With respect to planning, it may be that developers are seeking permissions that contravene development plans or are trying to alter existing permissions. The property industry also argue the system needs streamlining and simplifying. They also make the case that there are too many taxes and disincentives attached to building, such as development levies, VAT, stamp duty, and building regulation and control costs, that amount to a sizable proportion of any sale price. Crucially perhaps has been the emergent tension between different types of investment finance in Irish property markets. In the post-crash era the state has introduced a series of new financial measures, including the establishment of NAMA and Real Estate Investment Trusts (REITs), which bundled together property portfolios, thus making it easier for international funds to invest in Irish property assets. The 
rate of return on these investments is often more favourable and seen to be less risky than it would be to invest in new construction projects. This is likely to be having a negative effect on the ability of Irish property developers to raise finance for new development projects. NAMA's need for rental growth is likely to be one of the reasons the Government is refusing to give private tenants (the majority of those on social housing lists) relief through rent controls. By pushing for maximum commercial returns, NAMA is working against the interests of those looking for an affordable and secure home. It is continuing the speculativeasset approach to housing that fuelled the crisis. This promotes residential property as a commodity rather than a social good. In this sense, NAMA is facilitating a massive transfer of wealth created by the Irish people to foreign and domestic investors. The combination of these factors is fuelling a set of related supply-led crises that seems set to continue for a number of years until sufficiently addressed.

\section{Conclusion}

The last twenty five years has seen a tumultuous set of changes with regards to Ireland's housing sector and market. Throughout the entire period it has been in crises that have developed in three phases. In the first phase, there were crises of creating enough supply, very quickly rising prices to levels that were unaffordable for low and middle income households and reduced competitiveness, a significant increase in household debt and bank debt to precarious levels, over-zoning of land and dramatic price increases, the expansion of urban sprawl and long distance commuting. While such changes were celebrated by the property sector, politicians and the media, they placed significant stresses on households and fuelled a huge property sector bubble that placed the wider economy at risk. The unfolding of this phase was shaped by the adoption of a neoliberal ideas and practices with respect to governance and economy. This prioritised market-led development, deregulation, publicprivate partnerships, and low corporate taxation. Both construction and banking sectors saw a relaxation of regulatory oversight. The state started to withdraw from social housing provision, instead relying on the private rental sector, and when it did provide social housing it was through PPPs. While demand was high, the property sector was afforded a range of very generous tax breaks and incentives. Moreover, there was a laissez-faire, uncoordinated approach to housing and planning policy. The planning system became developer-led, being pro-growth in ethos with a presumption for development operating, and was consistently undermined by localism, clientelism, and cronyism. In short, Irish policy was uncoordinated, 
piecemeal and favoured development interests, with too few checks and balances, thus enabling a property bubble to rapidly inflate, accompanied by an oversupply of stock.

The result was that when the property bubble burst, the fallout was catastrophic for households, the state, and the wider economy. House prices plunged, estates remained unfinished, households were faced with extensive mortgage arrears and negative equity or poor build quality, the social housing waiting list extended, and more households became homelessness. Rather than a radical change in policy, however, the Irish government's response to the crash was to persist with the same neoliberal ethos, protecting the interests of the banking and development sector through bank bailouts and the creation of NAMA, to enforce austerity measures that placed significant stresses on households, and to make little to no changes to housing and planning policy other than to significantly cut the resourcing of the responsible departments and local authorities and to massively reduce capital spend on regeneration and new social housing stock. Indeed, most policy has been a minimal effort, minimal cost in nature, with few legislative and policy changes, and a hope that the market returns and economy recovers and serendipitously fixes the problems. In part, this was due to the same government being in place post-crash as pre-, followed by diktats from the IMFEU-ECB as part of the sovereign debt bailout. But was also the result of an unwillingness to implement reform and put in place a strategic, coordinated approach to development. Instead, policy related to housing and planning remained fractured and fragmented in the years immediately after the crash, lacking any systematic or integrated framework.

Instead of the market returning and fixing the problems, a third phase in the crisis has emerged in which in selected areas demand has risen, oversupply has been mopped up, but no new supply is being created. This has driven up purchase and rental prices, but also created rising homelessness. The government response has been Construction 2020, a strategy that 'aims to ensure that necessary and sensible development can take place, and that it is not held back by unnecessary obstacles' (Irish Government 2014). It details 75 action points, though they are not framed within an overall holistic framework. However, rather than setting out concrete policies, it charts a roadmap for finding solutions rather than providing solutions, proposing a set of new committees, task forces, review groups, and consultations. Seven years after the crash started and much inaction there is now a strategy for thinking about action. Key elements of the strategy such as the revised national spatial strategy will not be in place until the end of 2015, let alone implemented. Just as supply and demand became disconnected in the Celtic Tiger years, policy responses and the post-crash crises have 
become disconnected, hopelessly out of sync with each other in terms of the actions needed and the temporal speed and resourcing required. The consequence is that the stresses and pressures of a failing housing sector and austerity measures continues to bear down on households, with international speculative finance once again driving property prices.

In our view, two things need to happen to help address the crises we have discussed. First, the government needs to fast-track Construction 2020, reframing it into a holistic, sustainable and non-cyclical approach to housing and planning -- that frames them as a sector and public good, not a simply a vehicle for capital accumulation -- and to start implementing policy and programmes. At the top of the agenda must be resolving unfinished estates, making them safe and attractive places to live, to prioritize creating supply in selected areas including an extensive social housing building programme, and to tackle the issue of homelessness. We appreciate that to date policy making in Ireland has been piecemeal, with different elements introduced at different times by varying governments and ministers with different ideological ambitions and a limited time horizon (the next election as opposed to fifty years time), and also the multi-scalar and multi-agency nature of delivery and governance of housing, and the diversity vested interests with different modus operandi and ambitions operating in the sector and seeking to influence policy and delivery. However, it is vital that a holistic approach is quickly established and enacted, rather than becoming bogged down in politics and inaction (it is interesting that policy to guarantee banks and bailouts costing billions can be taken overnight, but measures to tackle long-term housing crises can be neglected for years).

Second, the government needs to lessen austerity measures and be a more pro-active player in the housing sector, using construction and investment in social housing and selected public infrastructure as a way of tackling housing issues at the same time as growing the economy, as well as taking a more active role in the private rented sector. This includes using NAMA to provide sites, stock and finance for the provision of social and private housing without seeking to gain maximum commercial return thus over-inflating prices. The private rented sector now accounts for a fifth of all households and in urban centres it is even more significant with almost $40 \%$ of people renting in Galway, 35\% in Dublin, and 29\% in Cork. Government could pass regulation to restrict the rate of rent inflation in any one tax year to, for example, 5\%, and then recouping a higher rate of tax on rental incomes where a landlord has breached this cap. However, there are no moves to do so. The reason is that housing policy remains dominated by the interests of the property industry including the 
banks, developers, estate agents, solicitors, landlords, and increasingly, international capital and vulture fund investors who are buying up huge swathes of Irish residential property, who all seek rapidly rising property prices. Unless there is a more pro-active, coordinated response the crises of phase two will effect households for much longer, and the crises of phase three will deepen, worsen, and last for much longer.

\section{References}

Aalbers, M. B. (2008). The financialization of home and the mortgage market crisis. competition \& change, 12(2), 148-166.

Bacon, P. and Associates (2009) Over-capacity in the Irish Hotel Industry and Required Elements of a Recovery Programme http://www.ihf.ie/press/documents/HotelStudyFinalReport101109.pdf

Brawn, D. (2009) Ireland's House Party: What Estates Agents Don't Want You to Know (Gill and Macmillan, Dublin)

CBRE (2010) 2010 Q2 Dublin Retail Market Review http://www.cbre.ie/ie_en/research/research_content/research_right_col/CBRE_RetailQ2_0.pd $\mathrm{f}$

Central Bank (2013) Residential Mortgage Arrears and Repossessions Statistics: September 2013. http://www.centralbank.ie/polstats/stats/mortgagearrears/Documents/2013q3_ie_mortgage_ar rears_statistics.pdf

Central Bank (2014) Residential Mortgage Arrears and Repossessions Statistics: September 2014.

http://www.centralbank.ie/polstats/stats/mortgagearrears/Documents/2014q3_ie_mortgage_ar rears_statistics.pdf 
CSO (2008) Construction and Housing in Ireland

http://www.eirestat.cso.ie/releasespublications/

documents/construction/current/constructhousing.pdf

CSO (2012) Profile 4 The Roof over our Heads - Housing in Ireland. Dublin.

http://www.cso.ie/en/census/census2011reports/census2011profile4theroofoverourheads-

housinginireland/

CSO (2014a) Irish censuses. http://www.cso.ie/en/census/

CSO (2014b) Residential Property Price Index.

http://www.cso.ie/en/releasesandpublications/er/rppi/residentialpropertypriceindexaugust201

4

CSO (2014c) Quarterly National Household Survey.

http://www.cso.ie/px/pxeirestat/Statire/SelectVarVal/Define.asp?maintable=QNQ22

Daft.ie (2014) Daft.ie property report. https://c0.dmstatic.com/613/report/Daft-RentalReport-Q3-2014.pdf

DECLG (2005) Housing policy framework: Building sustainable communities. Dublin. Stationery Office.

DECLG (2012) Report of Pyrite Panel.

http://www.environ.ie/en/PyriteReport/FileDownLoad,30735,en.pdf.

DECLG (2014) housing statistics.

http://www.environ.ie/en/Publications/StatisticsandRegularPublications/HousingStatistics/

Downey, D. D. (2014). The Financialisation of Irish Homeownership and the Impact of the

Global Financial Crisis. In Maclaren, A. and Kelly, S. (eds) Neoliberal Urban Policy and the Transformation of the City: Reshaping Dublin, 120-138. 
Hearne, R. (2011) Public Private Partnerships in Ireland: Failed experiment or way forward for the state. Manchester UK. Manchester University Press.

Honohan, P. (2010) The Irish Banking Crisis: Regulatory and Financial Stability Policy 2003 - 2008. Irish Central Bank, http://www.centralbank.ie/data/NewsFiles/The\%20Irish\%20Banking\%20 Crisis\%20Regulatory\%20and\%20Financial\%20Stability\%20Policy\%202003-2008.pdf Housing Agency (2010) 2010 National Housing Survey. http://www.housing.ie/OurServices/Unfinished-Housing-Developments/2010-National-Housing-Survey

Housing Agency (2011) Housing needs 2011. Dublin. Housing Agency.

Housing Agency (2013) 2013 National Housing Survey. http://www.housing.ie/OurServices/Unfinished-Housing-Developments/2013-National-Housing-Survey

Housing Agency (2014) Housing Supply Requirements in Ireland's Urban Settlements 2014 - 2018. http://www.housing.ie/Housing/media/Media/Publications/Future-Housing-SupplyRequirements-Report.pdf

Irish Government (2014) Construction 2020: A Strategy for a Renewed Construction Sector. http://www.taoiseach.gov.ie/eng/Publications/Publications_2014/Construction_Strategy__14_May_2014.pdf, May 2014

Irish Times (2014a) Rent supplement recipient numbers fall by 23\%. 24 Sept 2014. http://www.irishtimes.com/news/social-affairs/rent-supplement-recipient-numbers-fall-by-231.1939335

Irish Times (2014b) More social housing and funding are urgently needed. http://www.irishtimes.com/news/politics/more-social-housing-and-funding-are-urgentlyneeded-1.1777785 30 April. 
Kitchin, R., Gleeson, J., Keaveney, K. and O'Callaghan, C. (2010) A haunted landscape: housing and ghost estates in post-Celtic Tiger Ireland. Working Paper 59, National Institute for Regional and Spatial Analysis.

http://www.nuim.ie/nirsa/research/documents/WP59-A-Haunted-Landscape.pdf

Kitchin, R., O’Callaghan, C., Boyle, M., Gleeson J. and Keaveney, K. (2012) Placing neoliberalism: The rise and fall of Ireland's Celtic Tiger. Environment and Planning A 44(6): $1302-1326$

Kitchin, R. O'Callaghan, C. and Gleeson, J. (2014) The new ruins of Ireland? Unfinished estates in the post-Celtic Tiger era. International Journal of Urban and Regional Research 38(3): 1069-1080

Mahon, M. and O’Cinneide, M. (2010) Housing supply and residential segregation in Ireland, Urban Studies 47, 2983-3012

Morgenroth, E. (2014) Projected Population Change and Housing Demand: A County Level Analysis. QEC Research Notes 2014/2/3, ESRI, Dublin http://www.esri.ie/UserFiles/publications/RN20140203/RN20140203.pdf

Murphy. D. and Devlin, M. (2009) Banksters. Hachette Books, Dublin.

O’Toole, F. (2009) Ship of Fools: How Stupidity and Corruption Sank the Celtic Tiger. Faber and Faber, London.

O'Riain, S. (2014) The Rise and Fall of Ireland's Celtic Tiger: Liberalism, Boom, and Bust (Cambridge, Cambridge University Press)

RTÉ (2012) Over 50\% of Irish mortgages in negative equity-Davy, RTÉ News 17 August 2012, http://www.rte.ie/news/2012/0817/333979-negative-equity/

Savills HOK (2007) Values approach $€ 60,000$ hectare. Irish Agricultural Land Research May, http://www.savills.ie/pdfs/articles/166.pdf 
Savills HOK (2010) Dublin office market in minutes,

http://www.savills.ie/pdfs/market_watch/dublin-offi ce-market-in-minutes-q2-2010.pdf 